\author{
Стретович О.А. \\ кандидат економічних наук, доцент \\ кафедра менеджменту інноваційної діяльності \\ Національний університет біоресурсів і природокористування України \\ вулиця Героїв Оборони, 15, м. Київ, Україна, 03041 \\ E-mail: a.stretovich24@gmail.com
}

\title{
ТЕНДЕНЦІЇ РОБОТИ ЗЕРНОПЕРЕРОБНИХ ПІДПРИЄМСТВ УКРАЇНИ
}

У статті проаналізовано тенденції роботи зернопереробних підприємств України. Розглянуто економічні та організаційні умови в яких працюють великі підприємства по переробці зерна та мінімлини. Акцентовано увагу на негативних явищах, що впливають на розвиток ринкових відносин в зернопереробної галузі. Вказується на необхідність: конкуренції підприємств на стадії укладання договорів з покупцями; проведення тотального контролю за технологією виробництва; побудови тривалих партнерських відносин; стимулювання експорту борошна. Надані рекомендації щодо стратегії подальшого розвитку економіки підприємств даної галузі. робки зерна.

Ключові слова: ринкові відносини, економіка зернопереробних підприємств, продукти пере-

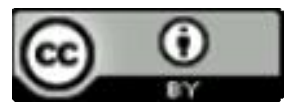

This work is licensed under a Creative Commons Attribution 4.0 International License http://creativecommons.org/licenses/by/4.0/

Постановка проблеми та їі зв'язок $з$ важливими науковими та практичними завданнями. Побудова ринкових відносин в Україні здійснюється певними шляхами, які частково повторюють історичний розвиток інших держав, але в більшості випадків мають свій оригінальний характер, обумовлений національним менталітетом і рівнем економічного розвитку суспільства. Існує багато причин об'єктивного i суб'єктивного характеру, за якими темпи освоєння ринкових відносин в нашій країні досить низькі. Основним недоліком роботи уряду, що призвів до такого стану справ, є відсутність чіткого уявлення про послідовність заходів, які слід проводити в даний час і на найближчу перспективу. Відсутність чітких планів призводить до стагнації економіки окремо взятих підприємств і країни в цілому.

Аналіз останніх публікацій 3 проблеми. Питанням раціонального функціонування зернопереробних підприємств України в ринкових умовах присвячені праці таких авторів, як: П.П.Борщевський, О.П.Верещинський, А.Г.Гончарук, І.В.Федулова, Р.Рибчинський, В.А.Самофатова, О.І.Шаповаленко, Н.С.Скопенко, І.О.Відоменко, О.Витвицька, В.Скрипниченко та ін.

Незважаючи на велику кількість публікацій та досліджень $з$ даного питання, періодично виникає потреба в проведені аналізу тенденцій роботи підприємств з переробки зерна в Україні.

Формулювання цілей дослідження. Ціллю статті $\epsilon$ аналіз тенденцій роботи зернопереробних підприємств України та надання певних рекомендацій щодо стратегії подальшого розвитку економіки підприємств даної галузі.

Виклад основних результатів та їх обгрунтування. Так, якщо проаналізувати роботу зернопе - реробних підприємств, то можна простежити, за деяким винятком, такі тенденції. Велике підприємство за власні або залучені фінансові кошти набуває зернові ресурси, які переробляє і продукти переробки пропонує для реалізації. Основними споживачами такої продукції традиційно є хлібопекарські підприємства, торговельна мережа, різні державні організації та установи (армія, лікарні, в’язниці, інтернати тощо), які знаходяться на бюджетному забезпеченні. Практично всім основним споживачам комбінат хлібопродуктів відвантажує продукцію 3 відстрочкою платежів, що в умовах неплатежів обертається «вимиванням» оборотних коштів. Розмір таких заморожених коштів збільшується 3 кожним виробничим циклом.

Одночасно на ринку зернових ресурсів існує багато дрібних і середніх операторів, які в результаті ряду бартерних і фінансових операцій мають пшеницю і жито більш дешеві, ніж та яку доводиться купувати великим підприємствам. Особливо якщо це ще й централізовані поставки 3 державних ресурсів або державного резерву. Важливу роль тут відіграє і можливість в наших умовах приватним фірмам працювати з готівковими коштами при закупівлі зерна.

Розуміючи, що прибуток від переробки зерна набагато перевищує прибуток від перекуповування i продажу зерна, приватні підприємці цілком логічно зайнялися переробкою зерна в основному за давальницькою схемою. В останні роки в Україні працює декілька тисяч міні-млинів. 3 огляду на неможливість тотального контролю на них якості одержуваного борошна, а також всіх технологічних вимог і стандартів, цілком реально припустити, що вони можуть задовольняти потреби тільки обмеженого ареалу спо живачів не вимогливих до якості продуктів перероб - 
ки зерна.

Переробивши зерно на давальницьких умовах, підприємці отримують борошно та інші продукти дешевші, ніж собівартість аналогічних продуктів зернопереробних підприємств. Пропонуючи великим споживачам борошна продукцію дешевше, давальці об'єктивно захоплюють ринки збуту, а можливість роботи з готівкою дозволяє їм успішно стимулювати своєчасність розрахунків за продукцію. Таким чином, сформувався ще один сегмент на ринку продуктів переробки зерна.

Велику увагу науковці та виробничники України приділяють підвищенню ефективності сортових хлібопекарських помолов пшениці і конкурентоспроможності борошномельних заводів різної продуктивності. За останній період отримало подальший розвиток наукове обгрунтування і практичне підтвердження можливості і доцільності скорочення структури сортових помолов пшениці на борошномельних заводах різної продуктивності за рахунок інтенсифікації переробки з використанням лущення зерна. Були виявлені закономірності технології лущення пов'язані зі зміною ступеня завантаження робочої зони обладнання для обробки поверхні зерна. Доведено можливість і доцільність інтенсифікації холодного методу водотепловой обробки (ВТО) зерна за рахунок його попереднього лущення, доцільність підготовки зерна до помелу із забезпеченням значення індексу лущення 6...8\%. Практики довели, що реалізація технології помолов пшениці 3 використанням лущення сприяє більш повному використанню потенціалу алейронового шару зерна для підвищення біологічної цінності борошна [2].

Істотна робота проводиться по оптимізації логістичних схем руху сировинних потоків і готової продукції. Виробничі потужності зернової галузі України представлені у всіх регіонах країни, проте лідерами з виробництва борошна і круп в Україні $є$ Донецька, Дніпропетровська, Харківська, Київська та Вінницька області, що виробляють в сукупності більш як третину всього обсягу. У той же час лідируючими регіонами зі збору зернових традиційно $\epsilon$ Одеська, Полтавська, Дніпропетровська та Кіровоградська області, а з виробництва хлібопродуктів Київ, Донецька, Дніпропетровська та Харківська області. Таким чином, найбільші об'єкти даної галузі територіально розташовані між основними джерелами сировини (зерна) і основними споживачами готової продукції, що сприяє мінімізації транспортних витрат [5].

Для відстоювання інтересів переробників зерна України в 2013 році з ініціативи 11 лідируючих підприємств країни було створено галузеве громадське об'єднання «Борошномельний союз України». Частка підприємств - засновників «Борошномельного союзу України» становить понад 20\% від загального обсягу виробництва борошна в країні і 19\% - від загального обсягу експорту зазначеної продукції.

Основними цілями професійного об'єднання $€$ консолідація діяльності підприємств галузі у відстоюванні їх інтересів, формування плану розвитку борошномельної та круп'яної промисловості України на середньо- та довгострокову перспективи, розширення асортименту борошномельної продукції для внутрішнього ринку і стимулювання експорту українського борошна, а також впровадження менеджменту якості на підприємствах галузі за стандартами ISO i системи управління харчовою безпекою під час всього виробничого процесу - НАССР [1].

Здавалося б, розвиток ринкових відносин у такому руслі цілком закономірний і мав би задовольняти всіх учасників ринку, але якщо даний процес проаналізувати уважніше, то не можна не помітити такі негативні явища:

- конкуренція на ринку продуктів переробки зерна відбувається на рівні готової продукції, що породжує перевиробництво, накопичення невиправданих запасів і як наслідок заморожування підприємствами оборотних коштів;

- невеликі постачальники борошна та інших продуктів переробки зерна не в змозі забезпечити стабільні запити споживачів. Як наслідок, великі зернопереробні підприємства знаходяться в «черговому» режимі;

- топ-менеджмент зернопереробних підприємств, будучи невпевненим у виконанні умов договорів із закупівлі продукції з боку хлібозаводів та інших великих споживачів, не ризикує брати кредити банків та проводити закупівлі великих партій зерна;

- на великих зернопереробних підприємствах відсутній явний власник, що одноособово впливає на розвиток економіки підприємства. Навіть якщо підприємство і приватизовано, то його майно часто розподілено між великою кількістю дрібних власників акцій. Істотно впливати на економічну політику підприємства, брати на себе ризик економічних наслідків того чи іншого рішення може тільки власник контрольного пакета акцій;

- при неритмічній роботі підприємства у працівників відбувається втрата почуття стабільності, в результаті чого виникає бажання швидкої і досить великої винагороди за результати своєї праці, незалежно від результатів роботи підприємства в цілому. У ринкових умовах такий підхід неможливий, оскільки ефективність роботи підприємства в першу чергу визначається не роботою кожного окремого підрозділу, а вдалим становищем підприємства на ринку конкретного продукту;

- витрати підприємства по переробці зерна в основному мають умовно-постійний характер, винятком $\epsilon$ витрати на сировину і електроенергію. Звідси на собівартість переробки 1 т зерна дуже сильно впливають обсяги переробки. При істотних коливаннях обсягів переробки за місяцями відбуваються великі коливання у витратах на 1 т продукції, що в свою чергу позначається на коливаннях собівартості продукції.

Висновки та перспективи подальших досліджень. Провівши аналіз ситуації, що склалася в роботі підприємств 3 переробки зерна, вважаємо за доцільне висловити наступні зауваження і рекомендації. 
1. Конкуренція на ринку повинна відбуватися на стадії укладення договорів, а не коли продукція вже вироблена і лежить на складі. Слід розширити i закріпити практику проведення тендерів 3 обов'язковими матеріальними санкціями за невиконання поставок продукції, зрив закупівель продукції, порушенням термінів і т.п. Суспільство може бути економічно сильним тільки за умови раціонального використання ресурсів. Робота на склад $є$ в певній мірі збиток. Впевненість в реалізації продукції дозволяє планувати раціональне використання виробничих потужностей, фінансових ресурсів, оптимізувати обсяги виробничих запасів.

Кожне підприємство досягає рівень беззбитковості при певному рівні використання виробничих потужностей. Знаючи, при якому рівні завантаження виробничих потужностей можлива беззбитковість виробництва, підприємство бореться за необхідний портфель замовлень.

Стабільність в певній мірі запорука успіху. Для великого підприємства предметом особливої тривоги $є$ не пошук ресурсів, їх в більшості випадків пропонують в достатній кількості, а встановлення тривалих партнерських відносин зі споживачами продукції;

2. Тільки на великих спеціалізованих підприємствах 3 переробки зерна можливо проводити безперервний контроль за основними показниками технологічного процесу, забезпечити достатній асортимент та високу якість харчових продуктів.

3. Виробник зерна сподівається на вдалий збут своєї продукції. Він з великим бажанням укладає ф'ючерсні і форвардні контракти, і тоді у нього 3'являється гарантія прибутковості здійснених фінансових витрат та впевненість у правильному виборі бізнесу. Виробники бажають довгострокових партнерських взаємин і в превалюючий більшості віддають перевагу економічним відносинам 3 великими промисловими підприємствами перед дрібними, економічно нестійкими, не передбачуваними в партнерських відносинах структурами.

Великі зернопереробні підприємства в свою чергу зацікавлені в тривалих партнерських відносинах, як із споживачами продуктів переробки, так і 3 постачальниками зернових ресурсів.

4. Для підвищення відповідальності (в першу чергу матеріальної) за ефективну роботу підприємств, слід більш швидкими темпами проводити приватизацію. Не слід боятися великих власників. Той, хто розгортає великий бізнес, не може піти з нього швидко.

5. Одним з серйозних чинників поліпшення роботи підприємств галузі є стимулювання експорту борошна. В цьому напрямку органам державної влади слід спрямувати зусилля і ресурси на:

- підвищення потенціалу фінансової системи держави 3 кредитування товаровиробників, 3 метою істотного стимулювання їх інноваційної діяльності;

- допомога в просування харчової продукції українських підприємств на ринки зарубіжних країн;

- зниження залізничних тарифів на перевезення продукції агропромислового комплексу на експорт;

- забезпечення фактичного повернення податку на додану вартість при експорті продукції підприємств сільського господарства і переробної промисловості [3].

Виконання висловлених рекомендацій дозволить стимулювати роботу зернопереробних підприємств України, а отже поліпшити загальну економічну ситуацію в країні.

\section{Література}

1. В Украине создан Мукомольный союз [Електронний ресурс] // АПК-Информ. - 2013. - Режим доступу до ресурсу: http://www.apk-inform.com/ru/news/1016338\#.WBG6QtKLQ4h.

2. Верещинський О. П. Наукові основи і практика підвищення ефективності сортових хлібопекарських помолов пшениці : автореф. дис. на здобуття наук. ступеня докт. техн. наук : спец. 05.18.02 «Технологія зернових, бобових, круп'яних продуктів і комбікормів, олійних і луб'яних культур» / Верещинський О.П. - Київ, 2013. $-35 \mathrm{c}$.

3. Государство забыло о мукомолах? [Електронний ресурс] // Agronews. - 2015. - Режим доступу до pecypcy: http://agronews.ua/node/57098.

4. ЄС відкрив квоту для українських виробників борошна [Електронний ресурс] // Економічна правда. - 2016. - Режим доступу до ресурсу: http://www.epravda.com.ua/news/2016/02/4/579914/.

5. Про ефективність роботи зернопереробної галузі України [Електронний ресурс] // За матеріалами журналу «Пекар» (м.Мінськ, Білорусь). - Режим доступу до ресурсу: http://www.meatbusiness.ua/article.php?p=502\&j=1.

6. Скопенко Н. С. Сучасні тенденції інтеграції та концентрації в хлібопекарській галузі України / Н. С. Скопенко, О. А. Стретович // Наукові праці Одеської національної академії харчових технологій. - Одеса: ОНАХТ, 2010. - Вип. 38, Том 1. - С. 420-424.

7. Стретович О. А. Дослідження економічної ефективності використання сухої пшеничної клейковини на борошномельних підприємствах / О. А. Стретович, І. В. Федулова // АгроИнКом. - 2010. - №1-3. - С. 58-61.

8. Стретович О. А. Економічна ефективність технологічних нововведень у підприємствах борошномельної галузі / О. А. Стретович // Економіка АПК. - 2010. - №5. - С. 74-78.

9. Стретович О.А. Економічне обгрунтування доцільності гранулювання висівок борошномельними підприємствами / О. А. Стретович, Н. С. Скопенко, В. Г. Бондарчук // АгроИнКом. - 2009. - №5-8. - С. 13-16. 
10. Федулова І. В. Методичні підходи до формування інноваційної стратегії підприємств хлібопекарної галузі / І. В. Федулова, О. А. Стретович // Економіка: проблеми теорії та практики : збірник наукових праць. Д.: ДНУ, 2006. - Вип. 214, Том 4. - С. 1186-1193.

Стаття надійшла 20.10.2016

Стаття прийнята до друку 3.11.2016

Доступно в мережі Internet 30.12.2016

\author{
Стретович А.А. \\ кандидат экономических наук, доцент \\ кафедра менеджмента инновационной деятельности, \\ Национальный университет биоресурсов и природопользования Украины, \\ улица Героев Обороны, 15, г. Киев, Украина, 03041 \\ E-mail: a.stretovich24@gmail.com
}

\title{
ТЕНДЕНЦИИ РАБОТЫ ЗЕРНОПЕРЕРАБАТЫВАЮЩИХ ПРЕДПРИЯТИЙ УКРАИНЫ
}

В статье проанализировано состояние работы зерноперерабатывающих предприятий Украины и даны рекомендации по стратегии дальнейшего развития экономики предприятий отрасли.

В работе зерноперерабатывающих предприятий существуют такие тенденции. Практически всем основным потребителям муки комбинат хлебопродуктов отгружает продукцию с отсрочкой платежей, что в условиях неплатежей оборачивается "вымыванием" оборотных средств. Размер таких замороженных средств увеличивается с каждым производственным циклом.

Одновременно на рынке зерновых ресурсов существует много мелких и средних операторов, которые в результате ряда бартерных и финансовых операций имеют пшеницу и рожь более дешевые, чем те которые приходится покупать крупным предприятиям. Понимая, что прибыль от переработки зерна намного превышает прибыль от перекупки и продажи зерна, частные предприниматели вполне логично занялись переработкой зерна в основном по давальческой схеме.

Развитие рыночных отношений в таком русле вполне закономерно и должно удовлетворять всех участников рынка. Но, если данный процесс проанализировать внимательнее, то нельзя не заметить некоторые негативные явления:

- конкуренция на рынке продуктов переработки зерна происходит на уровне готовой продукции, что порождает перепроизводство, накопление неоправданных запасов и как следствие замораживания предприятиями оборотных средств;

- небольшие поставщики муки и других продуктов переработки зерна не в состоянии обеспечить стабильные запросы потребителей. Как следствие, большие зерноперерабатывающие предприятия находятся в "дежурном" режиме;

- при неритмичной работе предприятия, у работников происходит потеря чувства стабильности, в результате чего возникает желание быстрого и достаточно большого вознаграждения за результаты своего труда, независимо от результатов работы предприятия в целом;

- в силу специфики экономики предприятий по переработке зерна, при существенных колебаниях объемов переработки по месяцам, происходят большие колебания в расходах на 1 т продукции, что в свою очередь сказывается на колебаниях себестоимости продукции.

Ключевые слова: рыночные отношения, экономика зерноперерабатывающих предприятий, продукты переработки зерна.

\section{Stretovych 0.}

Ph.D. in Economics, Associate Professor

Department of Management innovation

National Agriculture University of Ukraine

street of Heroes Oboronu, 15, Kyiv, Ukraine, 03041

E-mail: a.stretovich24@gmail.com

\section{WORK TRENDS GRAIN PROCESSING ENTERPRISES OF UKRAINE}

The article analyzes the work of grain processing enterprises of Ukraine and recommendations on the strategy for the further economic development of the industry. 
In the grain processing enterprises there are such tendencies. Almost all major consumers of bread flour plant ships products with deferred payments, non-payments under wraps "washout" of working capital. The size of these frozen funds increases with each production cycle.

At the same time on the market of grain resources, there are many small and medium-sized operators, which as a result of a number of barter and financial transactions have wheat and rye cheaper, than those who have to buy large enterprises. Realizing that the profits from the processing of grain far exceeds the profits from the repurchase and sale of grain, private entrepreneurs engaged in quite logical processing of grain mainly on tolling scheme.

The development of market relations in this vein is quite natural and should satisfy all market participants. But if this process is to analyze carefully, you will notice some negative effects:

- competition in the market of grain by-products takes place at the level of the finished product, which generates overproduction, unnecessary accumulation of reserves and as a result the freezing of working capital enterprises;

- small suppliers of flour and other products of grain processing is not able to provide a stable consumer demand. As a consequence, a large processing enterprises are in "standby" mode;

- with spasmodic work of the enterprise, the employees is a loss of a sense of stability, resulting in a desire to fast and big enough reward for the results of their work, regardless of the results of the enterprise as a whole;

- due to the specifics of the economy grain processing, with significant fluctuations in monthly processing volume, there are large fluctuations in the 1 ton of production costs, which in turn affects the vibrations of the cost of production.

Keywords: market, economy grain processing enterprises, processed grains.

\section{References}

1. V Ukrayne sozdan Mukomolnbi soiuz. (2013). Retrieved 2016, from http://www.apkinform.com/ru/news/1016338\#.WBG6QtKLQ4h.

2. Vereshchynskyi, O. P. (2013). Naukovi osnovy i praktyka pidvyshchennia efektyvnosti sortovykh khlibopekarskykh pomolov pshenytsi. Kyiv.

3. Hosudarstvo zabыlo o mukomolakh? (2015). Retrieved 2016, from http://agronews.ua/node/57098.

4. IeS vidkryv kvotu dlia ukrainskykh vyrobnykiv boroshna. (2016). Retrieved 2016, from http://www.epravda.com.ua/news/2016/02/4/579914/.

5. Pro efektyvnist roboty zernopererobnoi haluzi Ukrainy. (2015). Retrieved 2016, from http://www.meatbusiness.ua/article.php? $\mathrm{p}=502 \& \mathrm{j}=1$.

6. Skopenko, N. S., \& Stretovych, O. A. (2010). Suchasni tendentsii intehratsii ta kontsentratsii v khlibopekarskii haluzi Ukrainy. Naukovi Pratsi Odeskoi Natsionalnoi Akademii Kharchovykh Tekhnolohii, 38(1), 420424.

7. Stretovych, O. A., \& Fedulova, I. V. (2010). Doslidzhennia ekonomichnoi efektyvnosti vykorystannia sukhoi pshenychnoi kleikovyny na boroshnomelnykh pidpryiemstvakh. AhroYnKom, 1-3, 58-61.

8. Stretovych, O. A. (2010). Ekonomichna efektyvnist tekhnolohichnykh novovveden u pidpryiemstvakh boroshnomelnoi haluzi. Ekonomika APK, 5, 74-78.

9. Stretovych, O. A., Skopenko, N. S., \& Bondarchuk, V. H. (2009). Ekonomichne obgruntuvannia dotsilnosti hranuliuvannia vysivok boroshnomelnymy pidpryiemstvamy. AhroYnKom, 5-8, 13-16.

10. Fedulova, I. V., \& Stretovych, O. A. (2006). Metodychni pidkhody do formuvannia innovatsiinoi stratehii pidpryiemstv khlibopekarnoi haluzi. Ekonomika: Problemy Teorii Ta Praktyky : Zbirnyk Naukovykh Prats, 214(4), 1186-1193. 